\title{
THE POTENTIAL BIODEGRADATION HYDROCARBONS OF PETROLEUM SLUDGE WASTE BY CELL BIOMASS SPONGE Callysppongia sp.
}

\author{
Ismail Marzuki $^{1 *}$, Alfian Noor ${ }^{2}$, Nursiah La Nafie ${ }^{2}$ and M. Natsir Djide ${ }^{3}$ \\ ${ }^{1}$ Academy of Chemical Analysis, Yapika Makassar, \\ ${ }^{2}$ Department of Chemistry, Faculty of Mathematics and Natural Sciences, Hasanuddin \\ University \\ ${ }^{3}$ Faculty of Pharmacy, Hasanuddin University \\ *Contact: ismailmz3773@gmail.com
}

\begin{abstract}
The toxicity of petroleum sludge is a serious threat to marine life. Necessary concrete steps petroleum contamination reduction through a search of potential marine materials degrade toxic components hydrocarbons. The sponge is one potential material reducing toxic properties of petroleum contamination. The research objective was to determine the potential Callyspongia $s p$ sponge against the degradation of petroleum hydrocarbon sludge. Four variations of treatment used to determine the potential of sponge biomass, namely: the treatment I, II, III and IV. Indicators degradation is the formation of gas, the smell fermentation, $\mathrm{pH}$ changes and increase in the absorbance of the suspension of media degradation. The level degradation each treatment is determined gravimetric method and the known hydrocarbon component changes by using GC-MS. Unidentified gas, the smell of fermentation and changes in media of $\mathrm{pH}$ on average degradation occurs on the 15 days of contact for all treatments. Data showed degradation occurs absorbance maximum at 2025 days to contact. The highest degradation rates indicated by IV treatment (26.93\%), III (24.84 \%), II (22.59 \%), and I: (18.20\%). Found 20 kinds of components in the waste sludge aliphatic petroleum to form a homologous series nC10-nC30, and two aromatic components, namely the 2.7-dimethyl naphthalene and 1.4-dimethyl azulene. Callyspongia $s p$ sponge biomass concluded at the highest IV treatment degrading aliphatic hydrocarbons, then treatment III, II and I, while the aromatic components are not degraded by biomass Callyspongia sp sponge at all treatments.
\end{abstract}

Keywords: Callyspongia sp, biomass, degradation, sewage sludge, aliphatic, aromatic, treatment, GC-MS

\section{INTRODUCTION}

Waste oil should handled
comprehensible because it contains
components toxic, mutagenic and carcinogenic, categorized as hazardous materials, toxic. Waste petroleum hydrocarbon contamination can occur in nearly all lines of petroleum activities ranging from exploration through refining process, the process upstream to downstream stages and could potentially result in the form of sludge waste petroleum (oil sludge) $[1,2]$.

The main content of petroleum contaminants slugde are aliphatic hydrocarbons, aromatic (PAH), other components such as organic substances and heavy metal components $[3,4,5,6]$.

The PAH component is hydrophobic, so it easily attaches to organic matter from solid particles formed micropolutan persistent in the 
environment. PAH is a toxic substance could damage marine life and the potential to disrupt the health of humans because it is toxic in nearly alls marine life $[7,8]$.

One alternative is the reduction of hydrocarbons contaminated environments with bioremediation technique, which is a technology that is environmentally friendly, effective and economical by utilizing the activity of microbes such as bacteria. This method expected to reduce the waste oil into products such as organic substances and components untoxic simple $[8,9]$. Methods and principles of bioremediation is performed aerobic biodegradation by microorganism activity $[9, \quad 10]$. Microorganisms used in methods of biodegradation are bacteria that have the ability to degrade crude oil known as hydrocarbono-clastic microorganisms, namely microorganisms capable of utilizing crude oil as a carbon source for growth. Bacteria are often using in bioremediation process because it has adaptability and high reproductive $[8,11]$.

The use bacteria for biodegradation of oil sludge contamination much done, because it is believed inexpensive and environmentally friendly but, only in scale microcosms, although did not rule carried out on a larger scale (marine environment) and are continuous, there are still very many obstacles to arrive at this stage, as factor of the marine environment as medium degradation difficult to ascertain, solar lighting, sea water temperature, $\mathrm{pH}$, type and concentration of microorganisms is needed, isolation and production of microorganisms, the certainty of time degradation, and volume oil sludge contamination $[12,13]$. Naturally have the ability to degrade the environment-polluting substances that enter into it through the biological and chemical processes. However, often times the pollution load on the environment is greater than the speed of degradation of the natural contaminants. As a result, pollutants will accumulate to form sedimentary $[14,15]$.
The oil sludge much biodegradation studies utilizing cells from potential material degrada-tion such as mangroves, algae, jellyfish, and the material at the site of the oil sludge contami-nation $[13,16]$, but it can only touch on certain areas, such as the material of mangrove generally found in coastal areas, algae live in shallow ocean surface area, and the material isolated from the location of hydrocarbon contamination [7, 13, 17, 18, 19].

Oil sludge contamination can occur in almost all marine waters, thus research on biodegradation of oil sludge can be direcly to the search of potential meteria that can found in most areas of the sea $[12,20]$.

Sponges are scattered marine life in shallow and deep marine areas. Sponges are multicellular metazoan animals, which are filter feeders porous, so that it becomes a habitat for microorganisms to nesting in the body $[20,21]$. Sponges know to be symbiotic with some types of bacteria, so it assumed that microsymbiont and sponge biomass is potentially material to degrade oil sludge. This thinking based on several facts that some types of sponges can be symbiotic with many microorganisms such as symbiosis sponge Callyspongia sp with Bacillus subthilis strain BAB1684 and Bacillus FLEXUS strain PHCDB20, 136 isolates of bacterial symbionts sponge Jaspis sp, symbionts sponge Theonella sp, Melophlus surassinoru Callyspongia sp by Bacillus subthilis and vibrio bacteria eltor $[4,7$, 11, 22]. Structure consists of sponge biomass fraction skeleton, debris and bacteria pellets which all potential as a material to degrade petroleum sludge $[23,24]$. Sponges are multicellular organisms that have full body pores and channels that allow water to circulate through them, consisting of jelly-like mesohyl sandwiched between two thin layers of cells. Sponges specialized form of cell can change into another kind, 
often migrate between the main cell layers and mesohyl [25, 26].

\section{METHODS \\ Material and tools}

Materials consisting of a sponge, the fraction of biomass sponge Callyspongia $s p$ extracted, sewage petroleum sludge waste (PSW), NPK $5 \%$ (5 g/100 mL aquabidesh), (composition $\mathrm{N}: 25 \%, \mathrm{P}_{2} \mathrm{O}_{5}: 12 \%$, and $\mathrm{K}_{2} \mathrm{O}: 12 \%$ ), dichloromethana GR merck, iso-octane standard of $691 \mathrm{ug} / \mathrm{mL}$ (CA54084-1), TCL PAH standard mix 162000 $\mu \mathrm{g} / \mathrm{mL}, \mathrm{CRM} 48905$ Supelco, Stone Mineral Salt Solution (SMSS): composition $1.8 \mathrm{~g}$ $\mathrm{K}_{2} \mathrm{HPO}_{4} ; 1.2 \mathrm{~g} \mathrm{KH}_{2} \mathrm{PO}_{4} ; 4.0 \mathrm{~g} \mathrm{NH}_{4} \mathrm{Cl} ; 0.2 \mathrm{~g}$, $\mathrm{MgSO}_{4} .7 \mathrm{H}_{2} \mathrm{O} ; \quad 0.1 \quad \mathrm{~g} \quad \mathrm{NaCl} ; \quad 0.01 \mathrm{~g}$ $\mathrm{FeSO}_{4} \cdot 7 \mathrm{H}_{2} \mathrm{O}$; and $1.000 \mathrm{~mL}$ of distilled water), $0.9 \% \mathrm{NaCl}$ physiological.

Tools consist of GC-MS [Agilent 7890], the operating conditions (maximum temperature $350{ }^{\circ} \mathrm{C}$, the increase in temperature of $10{ }^{0} \mathrm{C}$ every 5 minutes, pressure 18.406 psi, a carrier gas Helium, a speed of 150 $\mathrm{mL} / \mathrm{min}$, capillary column [Agilent 19019S436HP-5 ms], dimensions of $60 \mathrm{mx} 250 \mu \mathrm{m}$ x $\quad 0.25 \mu \mathrm{m}$, the pressure 18,406 psi, separation $26,128 \mathrm{~cm} / \mathrm{sec}$., a retention time of maximum 30 minutes), spectronik $20 \mathrm{D} *$ [Thermo E. Corp]. a wavelength of $600 \mathrm{~nm}$, set centrifugasi [DKC-1006T] 6 tube, blender [Philips AE105], filter of $0.2 \mu \mathrm{m}$ [millex-LH], shaker incubator [EnviroGenie], micro pipette [Dragon Onemed], set sheet analytic [Mettler PM-200], spoit, Universal $\mathrm{pH}$ paper Brands.

Characteristic sponge sampling location: the coordinate point 16.01036 ' 8 " LS and $116^{0} 48.23^{\prime} 6^{\prime \prime}$ BT, temperature 29 ${ }^{0} \mathrm{C}, 30 \%$ salinity, $\mathrm{pH} 7$, and a depth of 2.7 $\mathrm{m}$, while WPS results obtained from the storage tank processing number B 05, PT. Chevron Pacific, Dumai Riau, Indonesia $[20,22]$.

\section{Experiments}

Callyspongia sp sponge biomass (CSB) extractionis done in a manner: $5 \mathrm{~g}$ sample prepared sponge Callyspingia $s p$ in $3.5 \%$ formalin, diluted with sea water that has been filtered by the filter of $0.2 \mu \mathrm{L}$. Samples Callyspingia sp crushed in a blender, then the cell suspension of biomass was centrifuged for 5 minutes speed of $1,000 \mathrm{rpm}$ to separate cell biomass sponge of residue formed supernatant, and the supernatant was centrifuged again at 4,000 rpm for 10 minutes obtained pellet bacteria, fractions result centrifugation weighed to get weight $(\%)$ each cell fraction $[11,23$, 24]. Sponge biomass fractions mixeds together in a $500 \mathrm{~mL}$ volumetric flask, diluted with $0.9 \% \mathrm{NaCl}$ physiological to the limit mark [20, 23].

The degradation process done in a way prepared 32 pieces of volume 40 $\mathrm{mL}$ vial of sterile and divided into four groups each consisting of 8 pieces vial. Treatment I: no added NPK and not in a shaker; Broadcaster II: no plus NPK and shaker; Broadcaster III: NPK plus and not in the shaker and treatment IV: plus NPK and shaker. Each vial filled: $10 \mathrm{~mL}$ SMSS, 10 suspension CSB of suspension media degradation, added $\pm 1 \mathrm{~g}$ sample of the PSW, and each vial on treatment III and IV plus $5 \mathrm{~mL}$ of NPK $5 \%$, resulting in contact between the suspension CSB with PSW in media degradation, a contact time of 35 days $[16,27]$.

Measurements parameters degradation (formation of gas, the smell of fermentation, $\mathrm{pH}$, and absorbent media degradation) is performed every 5 days by taking 1 piece vial each treatment, suspension of media degradation and residual PSW not degraded separated by a separating funnel, suspension media degradation accommodated in the vial another absorbance measurement at $\lambda=600 \mathrm{~nm}$, while the rest of the PSW dissolved in 10 $\mathrm{mL}$ of dichloromethane GR, shaken until all dissolved, allowed to stand \pm 3 minutes to ensure all PSW soluble. Analysis of hydrocarbon components making up the waste petroleum sludge 
done by taking $50 \mathrm{~mL}$ of solution, waste petroleum sludge, diluted with $10 \mathrm{~mL}$ dichloromethane and samples must free of water before it analyzed by GC-MS [2, 27, 28, 29].

Measurement parameter degradation (formation of gas, the smell of fermentation, $\mathrm{pH}$, and the determination of the level of biodegradation is done by PSW diluted with dikloromethana, evaporated until all the solvent evaporates, and then weighed using the analytical balance Mettler AE-100. Note: All treatments carried out at a temperature $32{ }^{0} \mathrm{C}$, shaker with a speed of $100 \mathrm{rpm} \mathrm{[2,}$ 28, 29].

\section{RESULTS AND DISCUSSION}

Sample characteristics WPS types of chemical waste sludge is the result of chemical coagulation and flocculation, black, semi-solid embodiment, the water content: $4.4769 \%$ insoluble material: $0.7847 \%$, aliphatic components: $85.98 \%$, aromatic components; $3.03 \%$, and other components: $10.99 \%$.

BSC components and composition of the fractions in the form of skeleton (spicules and cell debris): $69.8 \%$; sponge cell fraction (choanosome): $18.8 \%$; and pellet bacteria: $11.3 \%$. Previous research reported that the sponge biomass components contain at least skeleton, degris, choanosome and bacterial cells [23, 24].

Parameter analysis of petroleum sludge waste degradation, as follows:

\section{Analysis of the formation of gas and odor degrade media fermentation suspension}

Gas formation and the smell of fermentation in media degradation at all treatments, as an indicator of the degradation of waste components petroleum sludge by CSB suspension. The formation of gas and smell of fermentation in media degradation identified in the contact time is different between treatments, indicating cell responses biomass sponge Callyspongia $s p$ against media degradation is different, due to differences in treatment, but generally concluded that it has CSB can adapt and be able to reduce the composition of the PSW. Observation the formation of gas and odor degradation fermentation media have been previously reported $[8,27$, 28].

Measurement of the $\mathrm{pH}$ of the suspension media degradation by contact time each treatment

Change in $\mathrm{pH}$ is an indicator that shows the degradation of the hydrocarbon components in the PSW. Change in media of $\mathrm{pH}$ degradation occurs in treatment II, III and IV, while the first treatment does not change the $\mathrm{pH}$. Range longest time change indicated a pH of 7 to 6 on IV treatment at 15-30 days of contact. shows that there has been a reform of the hydrocarbon component to form an acidic organic compounds that contribute to the acidification of media degradation. $\mathrm{pH}$ decrease was also seen in treatments II and III, but a decrease in the $\mathrm{pH}$ range is shorter than the IV treatment.

Another factor that contributed to the increased acidity of media degradation is an increase in cell size and increasing the number of cell colonies in the sponge biomass Callyspongia $s p$, causes increased cell performance, is directly proportional to the increase in the ability of microbes remodel hydrocarbon components in the PSW. An increase in cell size and number of colonies is estimated to occur in 2 phases (phase of growth), and phase 3 (stationary phase) bacterial growth usually occurs after a period of adaptation for several days [30, 31].

\section{Turbidity suspension through the media degradation absorbance measurements}

The maximum biodegradation process takes place or not can also be see in the value of the optical density (OD) suspension. Suspension absorbance change is one of the parameter which indicate the occurrence of biodegradation 
of the PSW. There are two factors that contribute to increase the absorbent suspension, first: the number of bacterial colonies increased and enlarged cell size causing the turbidity of the suspension increase consequently increases the absorbance value; The second increase in absorbance due to some of the products of biodegradation included in the suspension of media degradation. Absorbant media degradation suspension after contact between the sponge biomass waste Callyspongia $s p$ with PSW, shown in Figure 1.

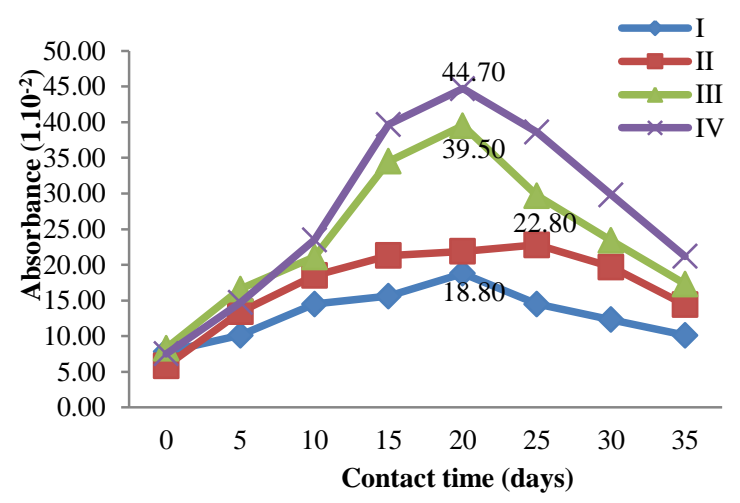

Figure 1 The relationship between the absorbance suspension degradation media with treatment based on contact time, measured at $\lambda_{\text {max. }}=600 \mathrm{~nm}$

Figure 1 shows the optimum absorption occurs for IV treatment at days 20 contacts (absorbance: 0.447) and decreased on days 25-35 of contacts. Similarly, treatment of first and second optimum uptake occurence at the contact days to 20, except for third treatment, optimum uptake occurs at the contact days to 25 . The decline in uptake on day 25 of contact for treatment of IV, II, I, and III treatment on day 30 contact indicates that the performance of bacteria in degrading hydrocarbon component decreases with the development of bacteria enter the death phase. Low absorbance value indicates the degradation process lasts less than the maximum, which is affected by a lack of nutrients and $\mathrm{O}_{2}$ supply, so that bacteria can not survive in extreme media.
The response of bacteria to PSW, to different treatment, resulting in a life time durability and degradation of bacteria in different media, because bacterial growth is influenced by food and environmental $[32,33]$.

\section{Determination of the extent of degradation by gravimetric methods}

Based on data absorbant, can be predicted that the rate of degradation hydrocarbons in the PSW by sponge Callyspongia $s p$ highest $\mathrm{sp}$ successive treatments indicated by IV, III, II and I. It was evident after analysis of the level of biodegradation that occurs as shown in Figure 2.

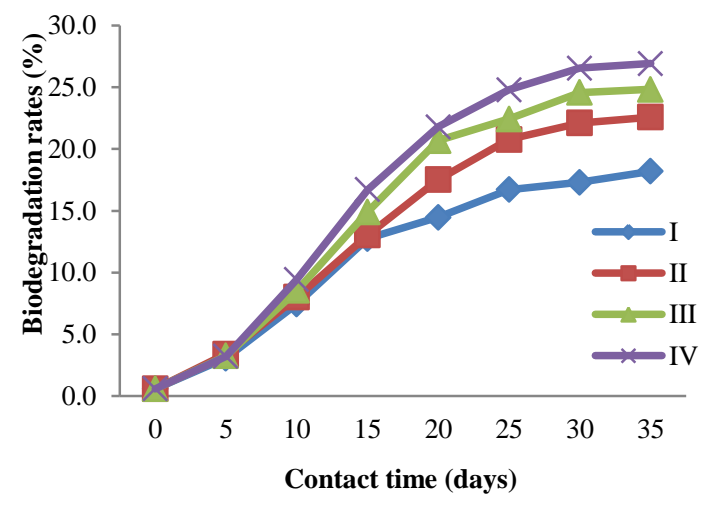

Figure 2 The relationship between the rate of biodegradation (\%) at the time of contact based treatment

Sequence maximum biodegradation rates in percent, namely IV treatment: (26.93), III (24.84), II (22.59), and I (18.20). The dominant biodegradation rates on IV treatment than other treatments began to appear on the contact day 10 to day 35 contacts. At the time of the contact of bacteria in a growth phase after a period of adaptation in contact day to $0-10$. Work bacteria in degrading hydrocarbon components PSW maximum waste occurs at the contact 1525 days, and is still going on contact 3035 days, but less than the maximum because the bacteria at that time already in the phase of death, the time when the number of colonies and size bacterial 
cells is reduced until finally alls colonies die.

The above results indicate that there is conformity between the absorbance, $\mathrm{pH}$ values, gas formation, fermentation odor degradation results obtained in each treatment. The combination of all parameters analyzed the degradation of the above it can be concluded that the most ideal IV treatment can improve the performance of bacteria to degrade the hydrocarbon components in the PSW. Analysis of the hydrocarbon components in the PSW are changing the measurement data interfretation GC-MS [13, 34].

Determination of the components and the concentration of hydrocarbons before and after degradation

Analysis of hydrocarbon components in the PSW before degrading can be seen on the chromatogram retention time Figure 3.

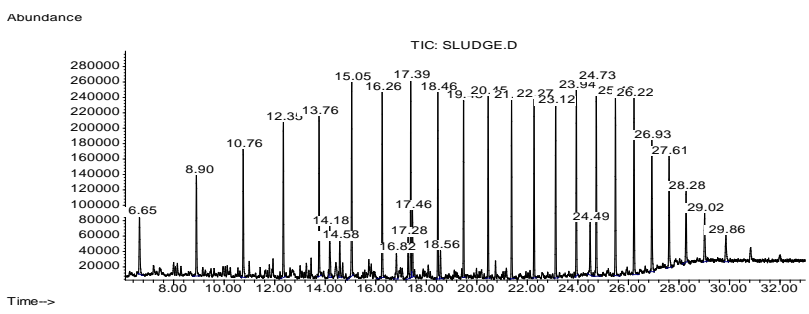

Figure 3 The relationship between the retention time (minutes) with an abundance of hydrocarbon component before it is PSW degraded.

Figure 3 showed the hydrocarbon components identified as many as 22 , which consists of 20 kinds of components straight chain aliphatic hydrocarbons $\mathrm{nC} 10-\mathrm{nC} 30$ and there are two aromatic components, namely 2.7-dimethyl naphtalena and 1.4dimethyl azulena. Comparison of the data retention time and abundance of hydrocarbon components after degradation based treatment showed significant changes.

Figure 4 showed the relationship between the retention time (minutes) with an abundance of hydrocarbon component after total degradation of the components contained in the PSW.

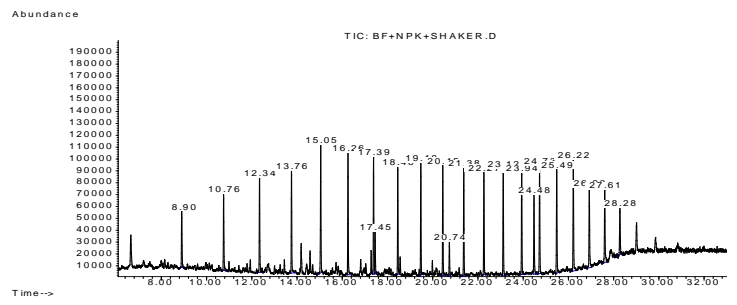

Figure 4. The relationship between the retention times (minutes) with an abundance of hydrocarbon components after degradation by CSB

GC chromatogram analysis based on the retention time of the relative abundance of hydrocarbon components showed changes on all treatments compared to the relative abundance of hydrocarbons before treatment. Figure 4 showed a decline in the abundance of hydrocarbon components in the PSW.

Changes in the composition the PSW before and after contact with a sponge biomass suspension Callyspongia $s p$ can be seen in the results of the GCMS data analysis and calculations based on peak areas of concentration changes and differences in the relative abundance of each component of the hydrocarbon at the same retention time, shown in figure 5 .

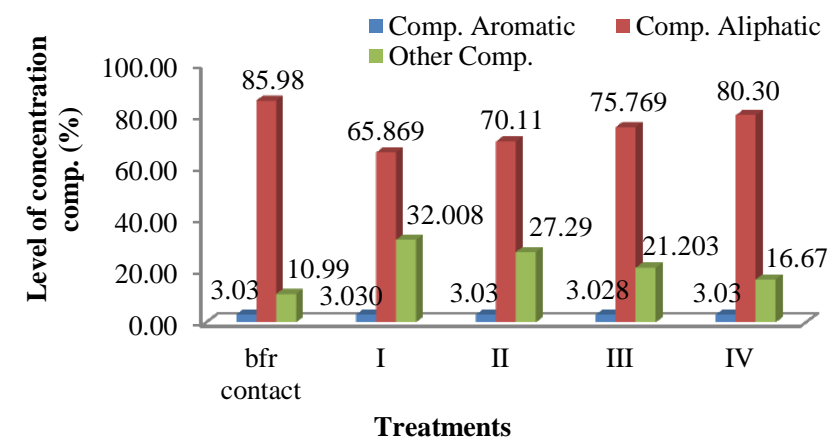

Figure 5 The relationship between treatment versus levels of concentrations component in petroleum sludge waste before and after contact 35 days with suspension Callyspongia $s p$ sponge biomass 
Petroleum sludge waste components of the composition of the waste prior to contact with the sponge biomass suspension Callyspongia sp based on peak area consists of three parts, namely aliphatic hydrocarbons $(85.98 \%), \quad$ aromatic hydrocarbons $(3.03 \%)$ and other components $(10.99 \%)$, experienced changes in the composition after contact for 35 days. Data Figure 5 shows the components of the change in the composition of the waste occurs at the highest petroleum sludge IV treatment, ie, aliphatic components $(80.30$ $\%$ ), aromatic components did not change and other components increased to (16.67 $\%$ ), basic components based on the determination of peak area, previously been reported in several studies $[4,10,35]$. Other components in the PSW actually increased, probably derived from aliphatic components are degraded into simple organic component, it is proved that the percent reduction in component aliphatic almost the same as the percent increase in other components.

Aromatic components did not change the concentration after contact between PSW with biomass sponge Callyspongia $\mathrm{sp}$ in media degradation, meaning biomass sponge Callyspongia sp in the fourth treatment can degrade aromatic components, (2.7-dimethyl naphthalene and 1.4-dimethyl azulene) in PSW.

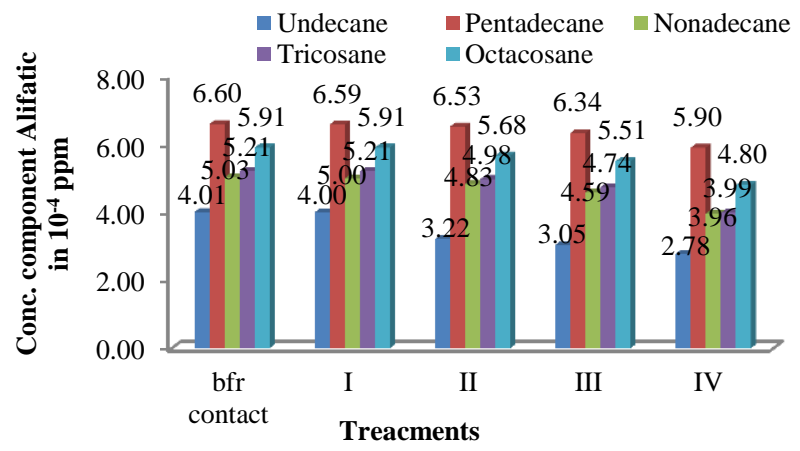

Figure 6 The relationship between treatment versus aliphatic hydrocarbons concentration in petroleum sludge was before and after contact 35 days with suspension Callyspongia $s p$ sponge biomass.
Figure 6 showed the changes in the concentration of component aliphatic nnormal alkanes (C11, C15, C19, C23, C27) after contact for 35 days.

GC-MS data analysis, showing changes in the concentration of component aliphatic hydrocarbon based waste treatment after contact between CSB which PSW suspension for 35 days. There five components of normal alkanes alkanes represent 20 components identified in the PSW. It appears that the decline observed at the highest concentration of IV treatment, namely: undecane (4.01 x $104 \mathrm{ppm})$ to $(2.78 \mathrm{x}$ $104 \mathrm{ppm})$; penthadecane (6.60x $104 \mathrm{ppm})$ to $(5,90 \times 104 \mathrm{ppm})$, nonadecane $(5,03 \times 104 \mathrm{ppm})$ to $(3.96 \mathrm{x} 104 \mathrm{ppm})$, tricosane $(5.21 \times 104 \mathrm{ppm})$ to $(3.99 \times$ $104 \mathrm{ppm})$ and octhacosane (5.91x104 $\mathrm{ppm})$ to $(4.80 \times 104 \mathrm{ppm})$. Treatments I, II, and III, also showed a decrease in the concentration of aliphatic hydrocarbons, but in narrower range than the decrease in IV treatment, so it is concluded that the treatment IV has the highest performance followed by treatment of III, II and I. Degrading aliphatic components in the PSW, The same results have been reported by some previous studies $[4,33,35]$

Petroleum sludge waste degradation mechanisms by Callyspongia $s p$ sponge biomass, begins breaking hydrocarbon components contained in petroleum by microbes as subtrak through oxidation processes involving oxygen as an electron acceptor. Oxygen plays a role in cellular metabolism as a reactant involved monooksige-nase enzyme, the enzyme catalyzing the subsequent entry of one oxygen atom into organic compounds. The $\mathrm{O}_{2}$ which joined the organic compounds in the form of hydroxyl ions $(\mathrm{OH})$ and the other oxygen atom to form a water molecule $[16,31$, 34]. 


\section{CONCLUSION}

Conclusions of study prove that the biomass sponge Callyspongia sp can degrade components of aliphatic hydrocarbons but not degrading aromatic components in petroleum sludge waste. Unidentified gas, the smell of fermentation and changes in media of $\mathrm{pH}$ on average degradation occurs on the 15 days of contact for all treatments. Data showed degradation occur absorbance maximum at 20-25 days of contact. Based on the highest performing degrading treatment in sewage sludge component aliphatic petroleum consecutive IV treatment: $(26.93 \%)$, III $(24.84 \%)$, II $(22.59 \%)$, and I $(18.20 \%)$. There are 20 kinds of components identified in the aliphatic petroleum waste sludge to form a homologous series nC10-nC30, and two aromatic components, namely the 2.7dimethyl naphthalene and 1.4-dimethyl azulene.

\section{REFERENCES}

[1] Ramdhani, Y., 2012. Kajian awal pemanfatan limbah lumpur minyak bumi (Sludge oil) menjadi bahan bakar padat, Laporan hasil penelitian JBPTPPOLBAN, Jakarta

[2] Aliyanta, B., Sumarlin O.L., Mujab S.A., 2011. Penggunaan Biokompos dalam Bioremediasi Lahan Tercemar Limbah Minyak Bumi, J. Valensi, vol. 2 (3):430-442

[3] Pradip, K. J., C.S. K. Mishra, D.K. Behera, S. Mishra, and L.B. Sukla, 2012. Dissolution of heavy metals from electrostatic precipitator Dust a Coal Based sponge Iron By Fungal Leaching, J. African of Environmental Science and Technology, vol. 6(4): 208-213

[4] Akinde, S.B., Iwuozor, C.C. and Obire, Omokaro, 2012. Alkane degradative potentials of bacteria isolat from the deep atlantic ocean of the Gulf of Guinea. J. Bioremed Biodegr., vol. 3 (1): $2-6$
[5] Ke Pan, On On Lee, Pei-Yuan Qian, Wen-Xiong Wang, 2011. Sponges and sediments as monitoring tools of metal contamination in the eastern coast of the Red Sea, Saudi Arabia, J. Marine Pollution, vol. 62: 11401146

[6] Li, Xuanzhen, Yucheng Wu, Xiangui Lin, Jing Zhang, Jun Zeng, 2012. Dissipation of polycyclic aromatic hydrocarbons (PAHs) in soil microcosms amended with mushroom cultivation substrate. J. Soil Biology \& Biochemistry, vol. 47: 191-197

[7] Wu, Yucheng, Ying Teng, Zhengao Li, Xuewei Liao, Yongming Luo, 2008. Potential role of polycyclic aromatic hydrocarbons (PAHs) oxidation by fungal laccase in the remediation of an aged contaminated soil. J. Soil Biology \& Biochemistry, vol. 40:789-796

[8] Gan, S., E.V. Lau, H.K. Ng, 2009. Remediation of soils contaminated with polycyclic aromatic hydrocarbons (PAHs). $J$ of Hazardous Materials, vol. 172: 532-549

[9] Okoh, A.L., 2006. Biodegradation alternative in the cleanup of petroleum hydrocarbon pollutants. J. Biotechnol. And Molecular Biology Review, vol. 1 (2): $38-50$

[10] Okoro, C.C., 2010. Application of seawater microbial inocula for the remediation of hydrocarbon polluted Mangrove Swamp in the Nigeria Oil Rich Niger Delta, Journal Nature and Science, vol. 8 (8): 152-162

[11]Ijah U. J. J., and L. I. Ukpe. 2008. Biodegradation of Crude Oil by Bacillus Strain 28A and 61B Isolated from Oil Spilled Soil. $J$. Waste Management, vol. 12: 5560 
[12] Romimohtarto, K \& Juwana, S., 2001. Biologi Laut, Ilmu Pengetahuan Tentang Biota Laut, Pusat Penelitian dan Pengembangan Oseanologi-LIPI. Jakarta. pp. 115-128.

[13] Syakti, D. A., Yani, M., Hidayati, V.N., Siregar, S.A. Doumeng, P., I.M. Sudiana, M., 2013. The Bioremediation potential of hydrocarbonoclastic bacteria isolated from a Mangrove Contaminated by Petroleum Hydrocarbons on the Cilacap Coast, Indonesia. $J$. Bioremediation, vol. 17 (1): 11-20, ISSN: 1088-9868 online. DOI: 10.1080.731446

[14]Rivas, F. Javier, 2006. Polyciclic aromatic hydrocarbons sorbed on soils: A short review of chemical oxidation based treatments. $J$. of Hazardous Materials B, vol. 138: 234-251

[15] Tapilatu Y, Acquaviva M, Guigue C, Miralles G, Bertrand JC., 2010. Isolation of alkane-degrading bacteria from deep-sea Mediterranean sediments. Letters in Applied Microbiology, vol. 50: 234236

[16] Okoh, A.I. 2003. Biodegradation Of Bonny Light Crude Oil In Soil Microcosm By Some Bacterial Strains Isolated From Crude Oil Flow Stations Saver Pits In Nigeria. African J. of Biotechnology, vol. 2 (5): 104-108

[17]Tam, N.F.Y and Wong, Y.S., 2008. Effectiveness of bacterial inoculum and mangrove plants on remediation of sediment contaminated with polycyclic aromatic hydrocarbons, Marine Pollution Bulletin, vol. 57: 716-728

[18]Lin, Y., and L. X. Cai, 2008. PAHdegrading microbial consortium and its pyrene-degrading plasmids from mangrove sediment samples in Huian, China. Marine Pollution Bulletin, vol. 57: 703-706
[19]Avecedo, Francisca, Lecticia, Pizzul, Maria, del Pilar Castilloc, Raphael, Cuevas, Maria, Cristina Diez, 2011. Degradation of Polyciclic aromatic hydrocarbons by the Chilean white-rot fungus Anthracophyllum discolor. J. of Hazardous Materials, 185, pp. 212-219

[20] Marzuki, I., Noor, A., Djide, N.M., La Nafie, N., 2014. Isolation and Identification on Degradator Bacterial of Petroleum waste which Symbionts with Sponge Callyspongis $s p$ from Melawai Beach. Proceeding: The 1st International Confrence on the sciences (ICOS), ISBN : 9786027219809, pp. 493-503

[21]Rachmaniar, R., 2007. Spons Indonesia Kawasan Timur. $J$. Oseanologi dan Limnologi Indonesia, vol. 3: 123-138

[22] Marzuki, I., Noor, A., Djide, N.M., La Nafie, N., 2015. Molecular characterization of gene $16 \mathrm{~S}$ rRNA micro symbionts in sponge at Melawai Beach, East Kalimantan. J. Marina Chimica Acta, 16 (1): 38-46

[23] Ismet, S.M., Soedharma, D., Effendi, H., 2011. Morphology and cell biomass of sponge Aaptos aaptos and Petrosia sp. $J$. Ilmu dan Teknologi Kelautan Tropis. vol. 3 (2): 153-16

[24]Meutia, S.P., Soedharma, D., Effendi, H., 2011. Morfologi dan biomassa sel spons Aaptos aaptos dan Petrosia sp. J. Ilmu dan Teknologi Kelutan Tropis, vol. 3, (2): 153-161

[25] Gazave E, Lapébie P, E Renard, Vacelet J, C Rocher, Ereskovsky AV, Lavrov DV, Borchiellini C, 2010. Filogeni molekuler mengembalikan subdivisi supragenerik spons homoscleromorph (Porifera, homoscleromorpha). J. PLoS 
One. 2010 Dec 14; 5 (12): e14290. doi : 10.1371/ journal.pone. 0014290

[26] Ruppert, E.E., Fox, R.S., and Barnes, R.D., 2004. Invertebrate Zoology, (7 ed.). Brooks / Cole. Pp. 76-97. ISBN 0-03-025982-7

[27] Nugroho, A., 2009. Produksi gas hasil biodegradasi minyak bumi: Kajian awal aplikasinya dalam microbial enhanced oil recovery (MEOR), $J$. Makara Sains, vol. 13 (2): 111-116

[28] Nugroho, A., 2006. Biodegradasi sludge minyak bumi dalam skala makrokosmos, J. Makara Teknologi, vol. 10 (2): 82-89

[29] Mariano, 2007. Laboratory study on the bioremediation of diesel oil contaminated soil from a petrol station. Braz. J. of Micro, vol. 38 (2): 346-353

[30] White R J., Patel J., Ottesen A., Arce G., Blackwelder P., Lopez V. J., 2012, "Pyrosequencing of Bacterial Symbionts within Axinella corrugata Sponges: Diversity and Seasonal Variability," www. plosone.org, e38204, J. PLoS ONE, 7(6), pp. 1-12

[31]Teng, Ying, Yongming Luo, Mingming Sun, Zengjun Liu, Zhengao Li, Peter Christie, 2010.
Effect of bioaugmentation by paracoccus sp. strain HPD-2 on the soil microbial community and removal of polycyclic aromatic hydrocarbons from an aged contaminated soil. J. Bioresource Technology. vol. 101: 3437-3443

[32] Yani, M., dan Akbar, Y., 2012. Proses biodegradasi minyak diesel oleh campuran bakteri pendegradasi hidrokarbon, Bioscientiae, J. Tekn. Industri Pertanian, vol. 19 (1): 4044

[33] Liu Z, Shao Z. 2007. The diversity of alkane degrading bacteria in the enrichments with deep sea sediment of the South China Sea. $J$. Wei Sheng Wu Xue Bao., vol. 47: 869-873

[34] Obire, O., Akinde, S.B., 2011. In-situ physic-chemical properties of the deep Atlantic Ocean water colum and implications on heterotrophic bacterial distribution in the guff of Guines, J. Advances in applied Science Research, vol. 2 (2): 470482

[35]Erdogan, Esin, and Karaca, Ayten. 2011. Bioremediation of Crude Oil Polluted Soils. Asian J. of Biotechnology, vol. 3 (3): 206-213 